\title{
Management on biotic stress to improve the nutmeg quality in North Moluccas, Indonesia
}

\author{
Muhammad Assagaf ${ }^{1 *}$, Isroi $^{2 *}$, Yayat Hidayat $^{1}$, Hermawati Cahyaningrum ${ }^{1}$, Abubakar \\ Ibrahim $^{1}$, Himawan Bayu Aji ${ }^{1}$, and Andriko Noto Susanto ${ }^{3 *}$ \\ ${ }^{1}$ North Moluccas Assessment Institute for Agricultural Technology, Sofifi, North Moluccas \\ ${ }^{2}$ Indonesian Research Institute for Biotechnology and Bioindustry, Bogor, Indonesia \\ ${ }^{3}$ Food Security Agency of the Ministry of Agriculture
}

\begin{abstract}
Indonesia dominates about $76 \%$ of nutmeg production and export in the world, where around $28.26 \%$ is produced in North Moluccas and $24.25 \%$ of its from North Halmahera. The objectives of this study were to reduce the biotic stress, increase the yield and improve the quality of the nutmeg produced by Tarakani Farmer Group in Galela District. (1) the Morphology of dry fruit rot disease in each stratum and (2) nutmeg cultivation system collected through interviews; and (3) climatic data, including temperature, and rainfall obtained from the Meteorology, Climatology, and Geophysics Agency of Galela District. This study was conducted at west Galela District and Tarakani Farmer Group. The farmers implemented the sanitation techniques of the crops; i.e.: pruning, collection and pile up/bury of the dropped fruits and fumigation by burning some leaves of local trees and biotic stress be controlled. During one year a grade A of nutmeg increased from 5.7 tons to 37.6 tons or increased from $17.6 \%$ to $38.2 \%$. Nutmeg grade $\mathrm{C}$ reduced from $40 \%$ to $25 \% \%$. This effort will still be forwarded by utilizing biological agents to reduce biotic stress, such as Trichoderma spp. to control fungal pathogens and Bacillus thurigiensis to pest control.
\end{abstract}

\section{Introduction}

Nutmeg is one of the important spice commodities in Indonesia. Nutmeg tree (Myristica fragrans Houtt), originally and endemic to the Maluku Island of Indonesia (formerly known as the Spice Islands), has long been of importance both as a spice and as a commodity that was once of geopolitical significance. Indonesia is the largest world producer and exporter of nutmeg with a world market share of $76 \%$ [1]. The main producing areas of nutmeg are North Moluccas, Moluccas, North Sulawesi, and Aceh.

The nutmeg fruit is a multipurpose fruit. Every part of the fruit could have economic value and is used in various industries. Nutmeg consists of pulp (77.8\%), mace (4\%), shell (5.1\%), and seeds (13.1\%) [2]. Parts of the export commodity are seed, mace, and nutmeg oil.

\footnotetext{
* Corresponding author: Assagaf: assagaf met@yahoo.com, Isroi: isroi93@gmail.com, Susanto: andriko notosusanto@yahoo.co.id
} 
Nutmeg oil is extracted from the seeds, mace, and leaves. Nutmeg products (seeds, mace, and oil) are used for the food industry, beverages, pharmaceuticals, perfumes, and cosmetics.

In the cultivation of nutmeg plants often experiencing problems, including disease and pest attacks result in a decrease in the quality and quantity of seeds and mace. One disease on nutmeg plants is dry fruit rot caused by the fungus Stigmina myristica Stein [12], and pests stem borer caused by Batocera Hercules Boisd [4, 5, 6].

Production and quality of nutmeg products are influenced by several factors, one of which is biotic stresses, such as pests and diseases. Indonesian nutmeg production decreased slightly in recent years. One cause of this decline may be due to the increase of biotic stress. It is necessary to control biotic stress so that the production and quality of Indonesian nutmeg have not influenced.

The objectives of this study were to reduce the biotic stress, increase the yield and improve the quality of the nutmeg produced by Tarakani Farmer Group in Galela District. The organic farming principles were applied by using organic fertilizer and biopesticides, such as Tricoderma spp and Bacillus thuringiensis. The training was conducted for the farmers to improve cultivation and post-harvest practices.

\section{Methods}

\subsection{Time and location}

The research was conducted in Dokulamo Village and Duma Village, West Galela District, North Halmahera Regency, North Maluku Province. The area of North Halmahera Regency, including a temperate climate. Air humidity ranges from $95 \%-99 \%$, with temperatures ranging from $26^{\circ} \mathrm{C}-43^{\circ} \mathrm{C}$. The rainfall in the North Halmahera Regency ranges from 1,500$4,500 \mathrm{~mm}$ per year. The highest rainfall $(2,500-4,500 \mathrm{~mm}$ per year) can be found in Galela and North Loloda with types A to C according to the Oldeman Classification.

\subsection{Respondents}

The 10 farmers as a sample of Tarakani Farmer group and each farmer was assigned 10 plants which were selected randomly to observe the intensity of dry fruit rot disease and stem borer pests. The research was carried out using direct observation or observation on the nutmeg plantation area belonging to the sample farmers and interviews with the farmers.

\subsection{Data collection and analysis}

Morphological observations of the causes of the disease were carried out. The research used a survey method. Each village (Dokulamo and Duma) was assigned 10 farmers as a sample of Tarakani Farmer group and each farmer was assigned 10 plants which were selected randomly to observe the intensity of dry fruit rot disease and stem borer pests. The research was carried out using direct observation or observation on the nutmeg plantation area belonging to the sample farmers and interviews with the farmers. The data collected included: (1) the Morphology of dry fruit rot disease in each stratum, and (2) climatic data, including temperature, humidity, and rainfall obtained from the Meteorology, Climatology and Geophysics Agency [7] of Galela District. To observe the quality of dried nutmeg seeds, observations were made from village-level collectors to district-level nutmeg traders. Determination of attack category diseases and pests are carried out based on average attack intensity by [9], ie disease intensity $0 \%$ (normal), $>0-25 \%$ (light), $>25 \%-50 \%$ (currently), $>50 \%-75 \%$ (severe), and $>75 \%$ (very severe). 


\section{Results and discussion}

\subsection{Nutmeg production of North Halmahera}

Nutmeg is one of the main commodities in North Moluccas province. In the year 2012, the total area of nutmeg crop was 28.864 ha with total production was 24,981 tons [8]. In the North Halmahera Regency, the total area of nutmeg crops was 6724 ha with the total production is 1600 tons [9]. Nutmeg production of North Halmahera in the last few years tended to slightly decline (Fig 1). The decline was not only in quantity but also in the quality of the nutmeg products. Nutmeg was planted by 4,355 families in 2012. This amount was increasing after the decrease in 2009. There are some new plantations or re-planting of nutmeg in North Halmahera (Fig. 2). In the next few years predicted that nutmeg production in North Halmahera would continue increasing.

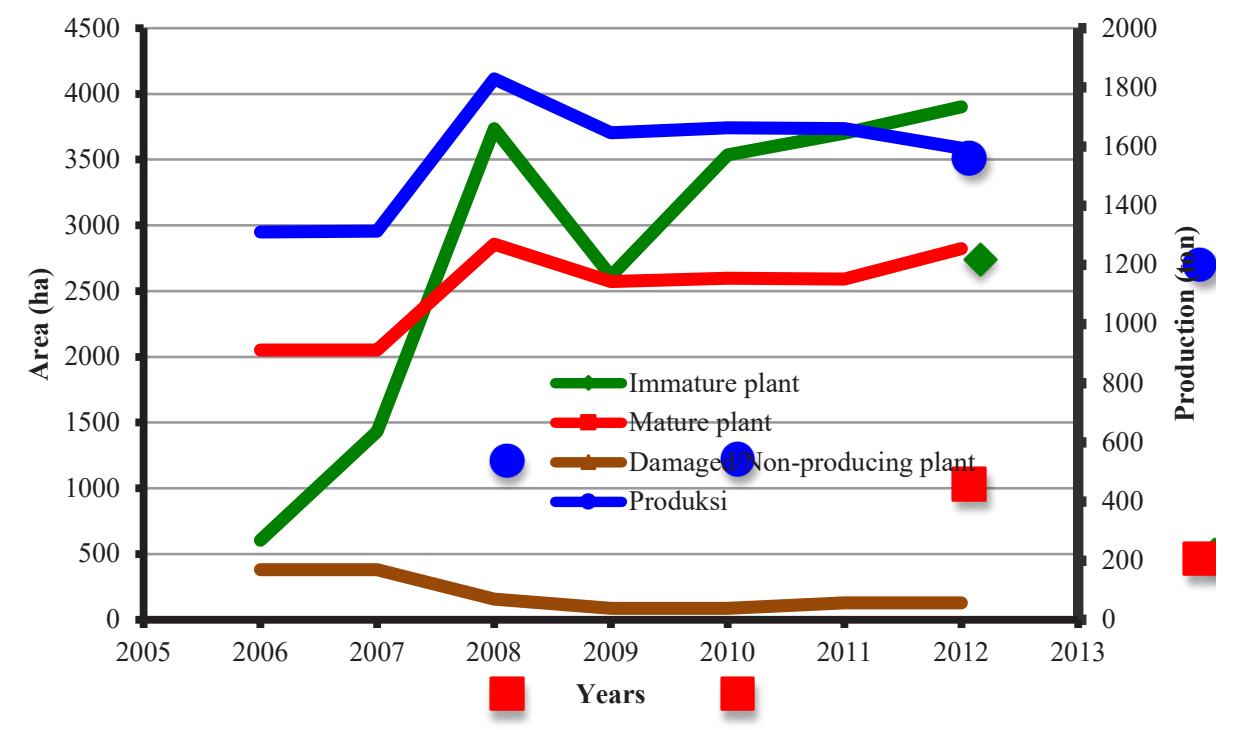

Fig 1. Nutmeg plantation area (ha) in North Halmahera during 2006-2012 (Data source: North Halmahera Local Departement of Agriculture, 2017).

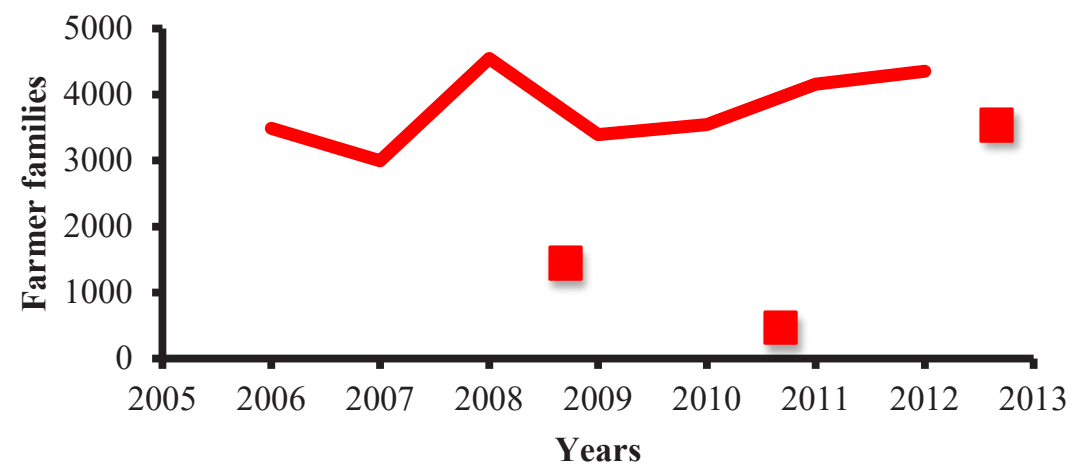

Fig 2. Dynamic of nutmeg farmer's families in North Halmahera

(Data source: Local Department of Agriculture North Halmahera, 2017) 


\subsection{Biotic stress in nutmeg crops}

Biotic stress of Nutmeg crops in North Halmahera caused by some disease, i.e.: immature fruit split, immature fruit drop, wet fruit rot, and dry fruit rot (Fig 3,4,5, and 6). These diseases are found almost in every area with different levels. The cause of immature fruit split and immature fruit drops was unknown. It could be caused by fungi or plant physiological aspects. Nutmeg and mace couldn't be harvested from the immature fruit. Wet and dry fruit rot is caused by fungi. An early symptom of this biotic stress is a black spot at the nutmeg surface and then becomes bigger and bigger. The fruit then will be drop. When the dropped fruit is mature, nutmeg and mace will be collected by farmers. Nutmeg and mace from this dropped fruit have very low quality.

At the research location, Galela District, North Halmahera, the ratio of hot days and rainy days per month in a year is quite high. Rainfall in this area is quite high with rainy days between 78 days and 64 days. The most rain in the past 5 years occurred in June 2015 for rainfall data reaching a maximum of $418.5 \mathrm{~mm}$ per month. Based on the data for 5 years obtained, it is known that the maximum daily rainfall in 24 hours is $142,389 \mathrm{~mm}$ [11]. The results of observations of disease intensity based on plant strata (Table 1) are classified as mild according to [9], but based on qualitative observations of attacks, it can be seen that the intensity of disease attacks in the upper level is lower than the middle and lower level, and the difference significantly. This can be seen in Dokulamo and Duma villages. This difference is thought to be influenced by sunlight, temperature, and micro humidity. In the upper level, the part of the plant that is exposed to sunlight is more than that of the plant in the middle and lower level. Radiation affects photosynthesis a lot for plant growth, besides that it affects the temperature and micro humidity around the plant which can affect the growth and development of disease-causing microorganisms such as fungi. This is reinforced by the high rainfall data in Galela District.

Table 1. The qualitative observations of fruit rot disease on various levels of nutmeg plants in Dokulamo and Duma Villages, West Galela.North Halmahera

\begin{tabular}{|l|c|c|}
\hline \multicolumn{1}{|c|}{ Level Plant } & Dokulamo Village & Duma Village \\
\hline Up & Light & Light \\
Middle & Currently & Currently \\
Lower & Currently & Currently \\
\hline
\end{tabular}

If it is associated with rainfall data in Galela Subdistrict which is quite high in 2015, then the potential for fruit rot disease and pest attacks can increase, so farmers need to carry out garden sanitation to minimize the potential for disease and pest attacks.

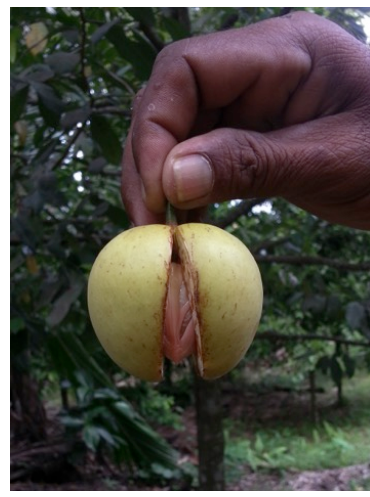

Fig 3. Symptom of immature fruit split of nutmeg

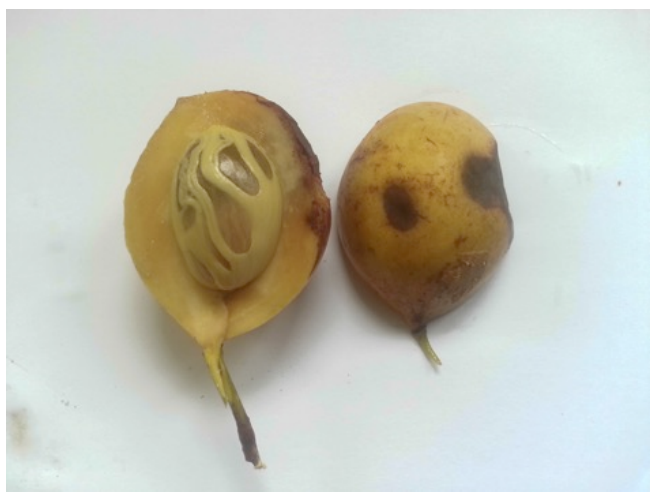

Fig 4. An Early symptom of fungal attack of the nutmeg 


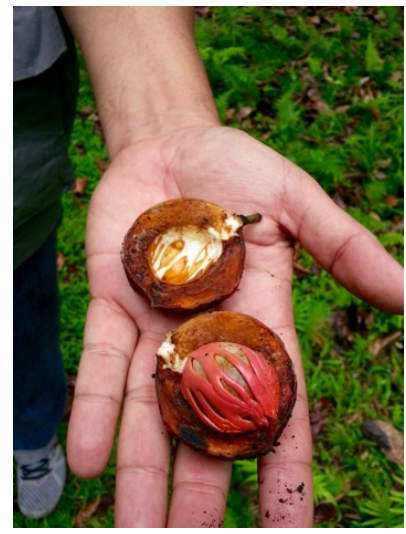

Fig 5. Wet fruit drop of the nutmeg

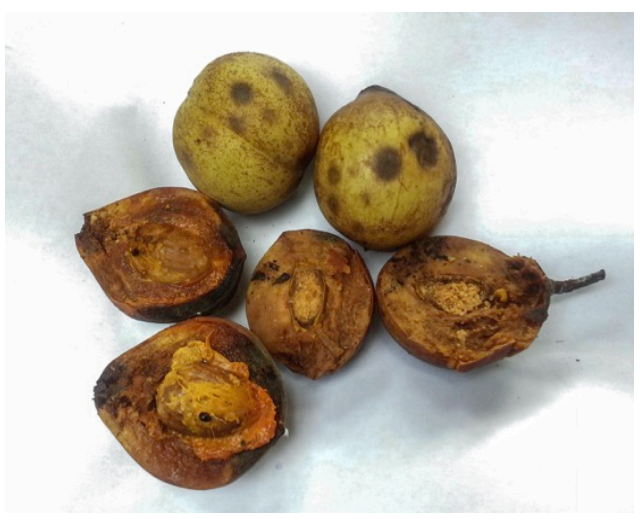

Fig 6. Young and Wet fruit drop of the nutmeg

\subsection{Biological control of biotic stress}

Biological control against biotic stress is one alternative to control the biotic stress without chemical compounds and meet with the organic agriculture practices. These strategies have been successfully implemented to control biotic stress in other crops. The most biological control agent to control biotic stress caused by fungi is Trichoderma spp [6] . Some insect acts as a vector to spread diseases and also larva of some insect live inside the nutmeg fruits. To control biotic stress caused by insects could be used Bacillus thuringiensis is a biological control agent. B. thuringinensis produce toxin for insect [12]. Application of biological control agents, such as Trichoderma spp and B. thuringiensis would be further applied in The North Halmahera nutmeg crops. This strategy expected could reduce the biotic stress of the nutmeg crops and improve the nutmeg quality. At this time, farmers from the Tarakani farmer group have made efforts to control disease and pest attacks by routinely cleaning the garden and burning biomass around the nutmeg garden.

\subsection{The nutmeg production effected at control biotic stress by Tarakani farmer group}

Tarakani Farmer Group (TFG) was established at Des 2013 in Galela, North Halmahera. TFG has 1205 members and at The year 2015 will be 3500 members. TFG arranges and manages cultivation management of nutmeg. TFG trains their farmer members to implement organic cultivation of nutmeg without using The chemical compound in cultivation and post-harvest processing of the nutmeg. To manage biotic stress in nutmeg plantations, TFG applies sanitation technic of the crops; i.e.: pruning, collection and pile up/bury of the dropped fruits and fumigation by burning some leaves of local trees.

Nutmeg received by TFG increased from 32.4 tons in January 2014 to 101.8 tons in December 2014. The Quality of the nutmeg also increased after the implementation of the organic cultivation system. Grade A of the nutmeg product increased from 5\% in January 2014 to $38.2 \%$ in December 2014 (Fig. 7). On the other hand, grade C of the nutmeg product decrease from $38.8 \%$ in January 2015 to $24.5 \%$ in December 2015. 


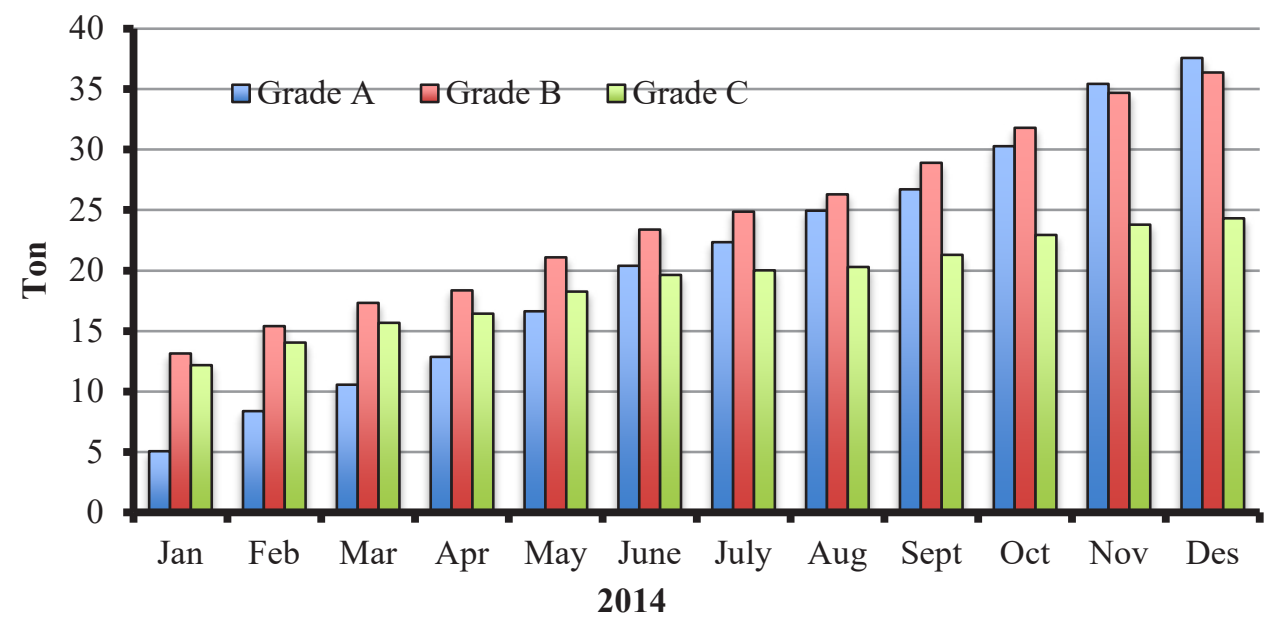

Fig 7. Nutmeg grade produced by Tarakani Farmer Group during 2014: grade A (blue bar), grade B (red bar), and grade C (green bar).

The quality of the nutmeg produced by the Tarakani farmer group consisting of grade A, grade $\mathrm{B}$, and grade $\mathrm{C}$, is presented in Figures 9,10, and 11 . The difference in the quality of nutmeg on the surface appearance of dry nutmeg is smooth for grade A and reduced in smoothness for below grade A.

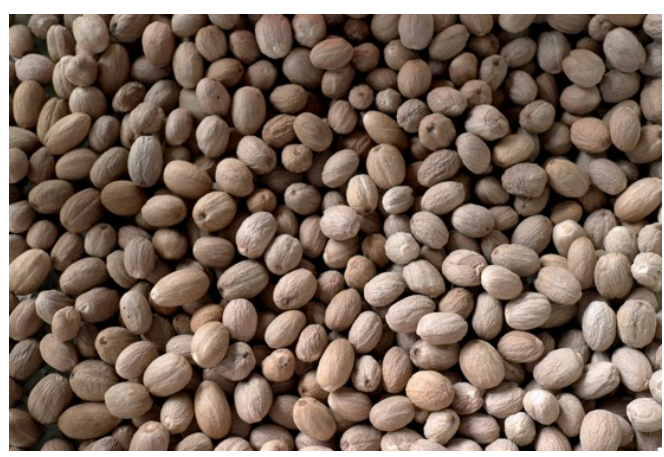

Fig 9. Nutmeg grade A

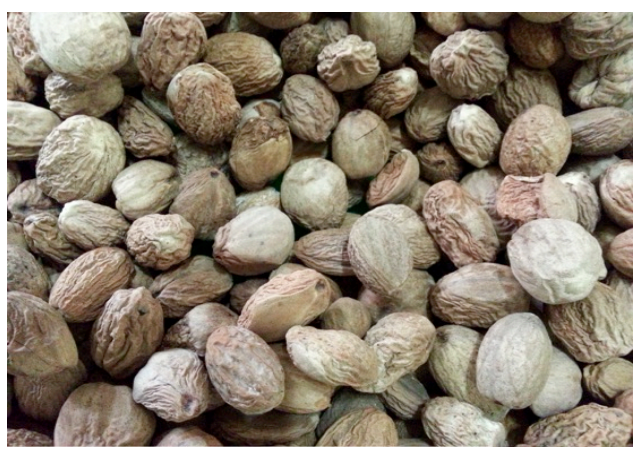

Fig 10. Nutmeg grade B

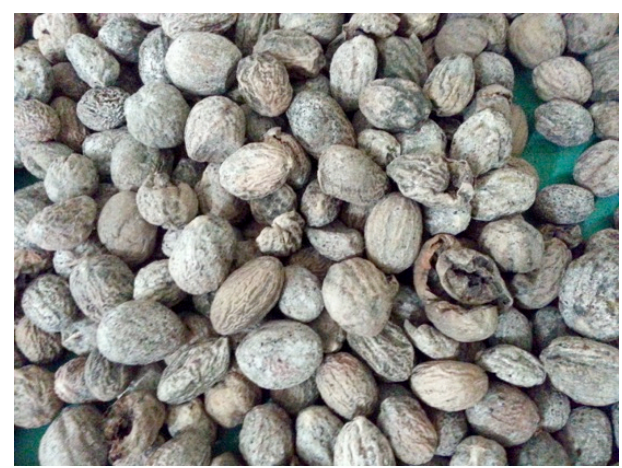

Fig 11. Nutmeg grade $\mathrm{C}$ 


\section{Conclusion}

Biotic stresses suppress the production and quality of the nutmeg in North Halmahera. By the implementation of the sanitation technic of the crops; i.e.: pruning, collection and pile up/bury of the dropped fruits and fumigation by burning some leaves of local trees and good agricultural practices biotic stress could be controlled. Quantity and quality of the nutmeg produced by TFG members significantly increased after one year. Biotic stress of the nutmeg crops could be further controlled by using biological control agents, such as Trichoderma spp and Bacillus thuringiensis. These biological agents could reduce the negative effect of biotic stress.

Acknowledgement: The authors would like to thank the three anonymous reviewers for their insightful suggestions and careful reading of the manuscript. This research was supported by Location Specific Agricultural Research And Development Partnership Activities Program from the Indonesian Agency for Agricultural Research and Development, Ministry of agriculture, Republic of Indonesia.

\section{References}

1. Marks, S. and J. Pomeroy. Bulletin of Indonesian Economic Studies. 31, 3: 103-118 (1995)

2. Rismunandar. Budidaya dan Tataniaga Pala. Jakarta, PT. Penebar Swadaya (1999)

3. Semangun, H. Penyakit Tanaman Perkebunan. Gadjah Mada University Press. Yogyakarta (2008)

4. Kalshoven, L.G.E. Pest of Crops In Indonesia. Revised Translated by P.A.Van Der Laan, the University of Amsterdam With the Assistance of G.H.L. Rothschild, Chiro, Canberra. PT. Ichtiar Baru - Van Hoeve. Jakarta (1981)

5. Pracaya. Hama dan Penyakit Tanaman. Edisi Revisi. Penerbit Penebar Swadaya. Jakarta (2008)

6. Agricultural Research and Development Agency. Pengendalian Terpadu Hama Dan Penyakit Utama Pala. Sinar Tani, Agroinovasi, Edisi 23 Pebruari - 1 Maret 2011 No.3394 Tahun XLI : 13-16 (2011).

7. BMKG. Data curah hujan Stasiun Ternate. Stasiun BMKG Kota Ternate (2017)

8. BPS. Halmahera Utara Dalam Angka.Halmahera Utara (2017)

9. Howell, C. R. "Mechanisms employed by Trichoderma species in the biological control of plant diseases: the history and evolution of current concepts." Plant disease 87.1 : 410 (2013)

10. Marks, S. and J. Pomeroy (1995). Bulletin of Indonesian Economic Studies 31, 3: 103 118 (1995)

11. Nurmansyah, Bul. Littro. 22,1: 65 - 73 (2011)

12. Entwistle, P. F., Cory, J. S., Bailey, M. J., \& Higgs, S. Bacillus thuringiensis: an environmental biopesticide: theory and practice. Wiley (1993) 